\title{
Franco Júnior, Hilário \\ Dando tratos à bola: ensaios sobre futebol
}

Bernardo Buarque de Hollanda* 1

São Paulo: Companhia das Letras, 2017. 464p.

Dez anos após a sua entrada "em campo", o historiador medievalista Hilário Franco Júnior, professor da Universidade de São Paulo, volta a oferecer ao público brasileiro um livro sobre futebol. Se em 2007 sua estreia no tema foi marcada por um trabalho de cunho sistemático, elaborado depois de longa maturação, Dando tratos à bola colige escritos esparsos do autor no último decênio. Parte deles é constituída de ensaios inéditos, enquanto a outra vem sendo publicada sob a forma de artigos em jornais de grande circulação e em periódicos científicos especializados.

É certo que a obra anterior apresentava um projeto mais ambicioso e completo. A dança dos deuses: futebol, sociedade, cultura propunha-se realizar uma macro e uma micro-História do mundo contemporâneo, com recortes longitudinais capazes de articular um Brasil "agrícola e mestiço, desigual e combinado" a uma Europa "industrial e colonialista, dividida e integrada”. Essas escalas e ordens de grandeza foram desenvolvidas sob uma perspectiva diacrônica, a cobrir um amplo painel histórico, que ia de meados do século XIX a princípios do século XXI. Em paralelo, o livro compreendia o esforço de examinar o futebol como metáfora dessa mesma contemporaneidade, a se valer de uma miríade de exemplos colhidos em cinco áreas de saber: a sociologia, a antropologia, a religião, a psicologia e a linguística.

Se a ambição e a completude do livro inaugural acedem aqui a textos pontuais, motivados por circunstâncias excepcionais, como a realização da Copa do Mundo de 2014 no Brasil, o resultado atualiza o acompanhamento que Franco Jr. faz de seu tema. A adoção do ensaio como gênero narrativo, que tantos frutos legou à tradição do pensamento social brasileiro e dos estudos histórico-literários, confere ao autor liberdade para transitar pelas temáticas mais

\footnotetext{
* Fundação Getúlio Vargas, Escola de Ciências Sociais. Rio de Janeiro, RJ, Brasil. bernardobuarque@ gmail.com
} 
díspares e pelas situações mais inusitadas suscitadas pela prática do futebol profissional ao redor do mundo.

A publicação de inéditos em formato ensaístico compõe uma nova totalidade, estruturada no livro em seis partes: "Copa do Mundo"; "Em torno da Copa de 2014"; "Identidade, memória, sociedade"; "Personagens do jogo"; "O jogo"; e "Observando o observador". Essa disposição dá sentido ao modo como Hilário Franco Junior pensa o Brasil contemporâneo e o fenômeno futebolístico em dimensão global.

A abordagem do autor destaca-se por seu método de pesquisa e por seu processo de levantamento bibliográfico. Residente há muitos anos na França, sua bibliografia e seu material de consulta se diferenciam tanto dos estudos acadêmicos sobre o futebol no Brasil quanto dos escritos jornalísticos da imprensa esportiva local. Característica já presente no livro anterior, o acesso a obras de menor circulação no Brasil demarca um modo próprio de expor seus conhecimentos futebolísticos. O primeiro ponto a notar é a sua erudição, que possibilita trafegar com facilidade da história antiga à moderna, da estrutura à conjuntura, do conceito abstrato ao lance anódino de um jogo. Está-se diante de um historiador equipado de um arsenal de informações, muitas delas factuais e enciclopédicas, é bem verdade, mas que dão outro tipo de historicidade, de inteligibilidade e de concretude ao universo futebolístico.

A marca expositiva do historiador ampara-se em um tema-guia, seguido de um sem-número de casos e de exemplos extraídos de uma bibliografia que procura fugir ao crivo do território nacional. Desse ângulo, Franco Jr. procura enfrentar a tão decantada brasilidade, embora não considere neste caso que boa parte dessa crítica já venha sendo praticada, seja por parte da comunidade científica (Helal; Lovisolo; Soares, 2001), seja por parcela expressiva da crônica especializada (Kfouri, 2017; Tostão, 2016; Giorgetti, 2017).

Os livros, as revistas e os jornais que sustentam sua argumentação são na maioria estrangeiros, e poucos deles chegaram a circular no Brasil. Trata-se de referências que versam não apenas sobre futebol, mas também sobre as ciências humanas e até mesmo as ciências exatas. Consultadas diretamente em línguas alemã, francesa, espanhola, inglesa e italiana, as citações não constituem simples gesto de distinção e repercutem na fatura da obra, a pôr em prática exercícios de deslocamentos "de fora" e "para fora" do Brasil.

Com efeito, o autor confronta os renovados debates acerca da identidade nacional, supostamente encarnada na Seleção brasileira, e elabora uma crítica própria à alcunha "país do futebol". Se a metáfora se desgastou ainda mais após os polêmicos megaeventos esportivos e a "humilhante" derrota por 7 a 1 para 
a seleção alemã nas semifinais do Mundial de 2014, a coletânea traz um ensaio originalmente publicado em 2013, em que a imagem era alvo de objeções por parte do autor, somando-se a autores como Helal, Soares e Lovisolo que, em 2001, já se referiam a essa "invenção" (Helal; Lovisolo; Soares, 2001). Longe de ser uma questão de ordem apenas conceitual, o argumento agrega números concretos e estatísticas atualizadas, constituindo-se a seu juízo um critério diferencial decisivo para demonstrar a impropriedade do seu uso nos dias de hoje. Malgrado a utilização desses dados quantitativos possa ser questionada como prova cabal por pesquisadores menos afeitos a tal método, o autor levanta uma série de informações contemporâneas sobre médias de público frequentador de estádios, números de praticantes, equipamentos disponíveis, audiência de canais televisivos e vendagem de periódicos esportivos no Brasil, entre inúmeras outras variáveis, para dar evidências de que o culto ao futebol no país é inferior em cada um desses quesitos quando comparados a outros países.

Outro traço metodológico caro ao presente livro se articula com o anterior pela capacidade de armazenamento de materiais extraídos de jornais e revistas de esporte internacionais. $\mathrm{O}$ banco de dados acumulado pelo autor conduz o leitor por tempos e espaços distintos, iluminando, com uma torrente, às vezes excessiva, de exemplos, personagens e competições, clubes e selecionados, eventos e cenários ignotos do mundo do futebol.

Um gosto um tanto exagerado do autor pelo anedótico leva-o a dedicar muitas páginas à identificação de situações pitorescas sobre o goleiro das Índias Orientais Holandesas na Copa de 1938, sobre um jogador islandês que tomou parte na excursão do Arsenal de Londres ao Brasil, em 1949, ou ainda sobre a introdução de traves cilíndricas no Maracanã dos anos 1960. Como já frisado, tais informações só são possíveis porquanto se mobiliza uma profusão de fontes, que vão do periódico francês L'Auto à revista italiana Guerin Sportivo, do jornal britânico The Sunday Mirror ao periódico austríaco Kurier, do diário português $A$ Bola ao semanário inglês World Soccer, entre muitos outros meios informativos a que não se tem acesso costumeiro no Brasil.

O trânsito entre "o interdisciplinar da universidade e o unidirecional do jornalismo” permite a Hilário Franco Júnior enfrentar em igual proporção as questões internas (técnicas e táticas) e externas (sociais, culturais e políticas) do futebol. Se os pesquisadores acadêmicos foram criticados por José Miguel Wisnik em Veneno remédio (Wisnik, 2007), por quase nunca tratarem da dinâmica do jogo propriamente dito, tal reparo não se pode imputar a Dando tratos à bola. 
Em pelo menos três instigantes capítulos - "O treinador revolucionário", "A geometria variável das táticas" e "O tabuleiro do futebol" -, o autor demonstra conhecimento específico de toda a evolução da linguagem futebolística, das regras que a codificaram ao longo do tempo, da racionalidade associada às estratégias de ocupação dos espaços e das infindáveis análises combinatórias, franqueadas pelos sortilégios do acaso no jogo.

Em brevíssimas linhas, eis os traços de um livro dedicado à longa duração das relações entre futebol e cultura, com interesse acadêmico, mas também capaz de satisfazer um curioso e renitente boleiro, cronista ou antiquarista esportivo. Espelho da sociedade, ao mesmo tempo cristalino e dissimulado, o futebol é aqui tomado como vetor de fenômenos estruturais e conjunturais, que permitem ao autor pensar temas transversais como a guerra, a migração, o racismo, a geopolítica, a violência, a decadência e a rivalidade, entre inúmeros outros. Quanto à sociedade brasileira, a obra traz um balanço e um retrato em nada complacentes do Brasil do século XXI, na ressaca do "Mineirazo", do "Maracanazo social" e de tudo o mais que conturba a intrincada conjuntura política dos últimos anos.

\section{REFERENCIAS}

GIORGETTI, Ugo. Dando tratos à bola. O Estado de S. Paulo, São Paulo, 5 nov. 2017. HELAL, Ronaldo; LOVISOLO, Hugo; SOARES, Antonio Jorge. A invenção do país do futebol: mídia, raça e idolatria. Rio de Janeiro: Mauad, 2001.

KFOURI, Juca. Confesso que perdi: memórias. São Paulo: Companhia das Letras, 2017. TOSTÃO. Tempos vividos, sonhados e perdidos: um olhar sobre o futebol. São Paulo: Companhia das Letras, 2016.

WISNIK, José Miguel. Veneno remédio: o futebol e o Brasil. São Paulo: Companhia das Letras, 2007.

\section{NOTA}

${ }^{1}$ Professor-pesquisador da Escola de Ciências Sociais da Fundação Getúlio Vargas (CPDOC-FGV). Bolsista de produtividade em pesquisa do CNPq.

Resenha recebida em 19 de dezembro de 2017. Aprovada em 20 de fevereiro de 2018. 